\title{
XXII. On the circle, the sphere, the square, and the equilateral triangle
}

\section{Mr. James Utting}

To cite this article: Mr. James Utting (1822) XXII. On the circle, the sphere, the square, and the equilateral triangle, Philosophical Magazine Series 1, 59:286, 102-103, DOI:

$10.1080 / 14786442208652689$

To link to this article: http://dx.doi.org/10.1080/14786442208652689

册 Published online: 27 Jul 2009.

Submit your article to this journal $\sqsubset \pi$

Џll Article views: 2

Q View related articles $₫$ 


\section{[ 102$]$}

XXII. On the Circle, the Sphere, the Square, and the equilateral Triangle. By Mr. James UtTing.

To Dr. Tilloch.

DEAR SIR, - Snouid the following statement relative to the sides and areas of the $\odot, \square$, and equilateral $\triangle, \& \mathrm{c}$. be thought worthy a place in the Philosophical Magazine, it is at your service.

Circumference of a $\odot$ to diame- $\}$

ter unity $\ldots \ldots \ldots \ldots\} 3 \cdot 14159,26535,89793,23846$

Area of a $\odot$ to diameter unity $\quad \cdot 78539,81633,97448,30962$

Solidity of a sphere to diameter unity $\cdot 52359,87755,98298,87308$ The diameter of a $\odot=1$.

The side of the circum- $\}=1 \cdot 73205,08075,68877,29353$

The diameter of a $\odot=1$.

$\left.\begin{array}{c}\text { The side of the inscribed } \\ \text { equilateral } \triangle \ldots\end{array}\right\}=\cdot 86602,54037,84438,64676$

The diameter of a $\odot=1$.

The side of an equila- $\}=1 \cdot 34677,36870,856$

The diameter of $a \odot=1$.

The side of a $\square$ of the $\}=\cdot 85622,69254,52758,01365$

The diameter of a $\ddot{\odot}=1$.

The side of the inscrib- $7=\cdot 70710,67811,86547,52440$

The side of a $\square=1$.

The diameter of the cir- $\left.{ }^{-}\right\}=1 \cdot 41421,35623,73045,04880$

The side of a $\square=1$.

$\left.\begin{array}{c}\text { The side of the circum- } \\ \text { scribed } \triangle \ldots \quad \ldots\end{array}\right\}=2 \cdot 15470,05383,79251,52902$

The side of a $\square=1$.

The side of an equilate- -$\}=1 \cdot 51967,13713,03185,09466$

The side of an $\Delta=1$.

The diameter of its in- $\}=.57735,02691,59625,76451$

The side of an $\triangle=1$.

$\left.\begin{array}{c}\text { The diameter of its cir- } \\ \text { cumscribed } \odot \quad . .\end{array}\right\}=1 \cdot 15470,05383,79251,52902$

The side of an $\Delta=1$.

$\left.\begin{array}{c}\text { The diameter of a } \odot \text { of } \\ \text { equal area } \ldots \\ \ldots\end{array}\right\}=\cdot 74251,52492,857$ 
On the Circle, the Sphere, the Squate, and Triangle. 103 The side of an $\Delta=1$.

$\left.\begin{array}{c}\text { The side of the inscribed } \\ \square . . \quad \ldots \quad . .\end{array}\right\}=\cdot 46530,24295,51049,79947$ The side of an $\Delta=1$.

$\left.\begin{array}{ccc}\text { The side of } a & \square & \text { of } \\ \text { equal area } & . & . .\end{array}\right\}=\cdot 65803,70064,76246,23041$ The side of an $\triangle$ given to find its

area $\times$ the $\square$ of the side by $\} 0 \cdot 43301,27018,92219,32338$

The lines circumscribing a $\square$, and $\odot$, of the same area, are in proportion to each other as $3.54490,77018,11032,05460$, to $3 \cdot 14159$, \&c. Or, as 1. to $\cdot 88622,69254,52758,01365$.

The lines circumscribing a $\square$, and $\Delta$, of the same area, are as l. to $1 \cdot 51967,13713,03185,09466$.

The lines circumscribing an $\Delta$, and $\odot$, of the same area, are as 1 . to $\cdot 77756,01507,781066$.

The area of a hexagon to that of its circumscribing circle is as 1 . to $1 \cdot 20919,9576156$. Or, as $\$ 22699,33431,32688$ to 1 .

Lymn Regis, Nov. 15, 1821. JaMES UtTing.

Errata. - In the Table of the $\odot$ 's R.A. in degrees, \&c. vol. lvii. page 29 :

Argument.

R.A. Diff.

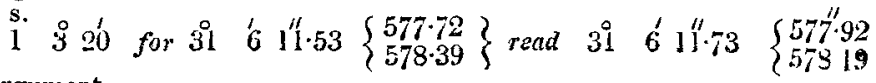
Argument.

s.

$\left.\begin{array}{lll}1 & 14 & 20 \\ 1 & 14 & 30 \\ 1 & 14 & 40\end{array}\right\}$ for $\left\{\begin{array}{ll}597^{\prime \prime} \cdot 76 \\ 597 & 98\end{array}\right\}$ read $\left\{\begin{array}{l}590676 \\ 596 \cdot 98\end{array}\right.$

$11440\}$ R.A.

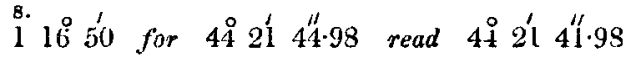

In the Table of the $\odot$ 's R.A. in time, page 184 :

Diff.

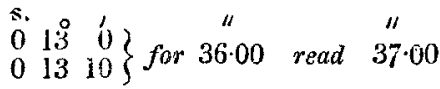

In the Reduction of the Ecliptic to the Equator, page 435 : Argument. Reduction.

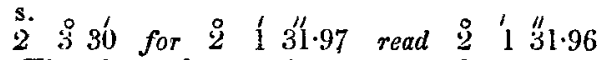

The signs, \&c. at the bottom of pages 435 and 436 are wrong inserted, they ought to be the same as at the bottom of pages 457 and 438 .

In the Table of the Var. of the $\odot$ 's R.A. and Decl, page 440 : Argument. Var. R.A.

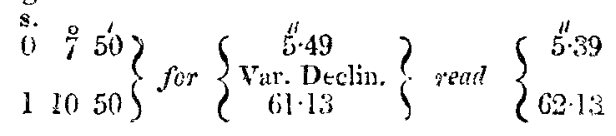

